\title{
Attitudes of Young People Towards Lakes as a Premise for Their Public Participation in Environmental Management
}

\author{
Małgorzata Cichon ${ }^{1}$, Weronika Warachowska ${ }^{2}$ and Damian Łowicki ${ }^{3 *}$ \\ ${ }^{1}$ Laboratory of Geography Didactics and Educational Research, Faculty of Geographical and Geological Sciences, Adam \\ Mickiewicz University, Poznań, Poland, ${ }^{2}$ Department of Geoinformation, Faculty of Geographical and Geological Sciences, Adam \\ Mickiewicz University, Poznań, Poland, ${ }^{3}$ Department of Integrated Geography, Faculty of Human Geography and Planning, Adam \\ Mickiewicz University, Poznań, Poland
}

OPEN ACCESS

Edited by:

Tracylee Clarke,

California State University, Channel Islands, United States

Reviewed by:

Stephen Holland University of Florida, United States

Clare Steele,

California State University, Channe Islands, United States

${ }^{*}$ Correspondence:

Damian Łowick

damek@amu.edu.pl

Specialty section: This article was submitted to

Science and Environmental Communication

a section of the journal

Frontiers in Environmental Science

Received: 23 March 2021 Accepted: 18 May 2021 Published: 04 June 2021

Citation:

Cichoń M, Warachowska W and Łowicki D (2021) Attitudes of Young People Towards Lakes as a Premise

for Their Public Participation in

Environmental Management.

Front. Environ. Sci. 9:683808.

doi: 10.3389/fenvs.2021.683808
Lake protection is a very important element of environmental management. This is especially true of lake districts, where the lakes are an important resting place for residents, especially young people. The crucial is the question whether young people who participate in lake management in the future, are ready for it. It was assumed that their attitude towards lakes would be an indicator of such preparation. This study aimed to define a set of respondents' features that may condition the specific model of participation. Based on the research conducted among young residents $(N=167)$ of the Szczecinecki District in Poland, it was found that their pro-environmental attitudes were dominated by high values of the traits that make up the emotional component, average values of the cognitive component and the lowest values of activity. The lower the score of the overall attitude, the more often the respondents chose Recreational Lakes, rather than General Development or Natural Lakes. The most important feature that may determine the level of participation in the future is readiness to act. A comprehensive attitude index was created, which shows that it is worth examining the characteristics of respondents that correlate with the willingness to act, i.e., knowledge, logical thinking, creativity and belief in the effectiveness of actions taken and attachment to the place of residence, when planning participatory management in lakeland areas.

Keywords: pro-environmental attitude, lakes, youth, environmental management, Poland

\section{INTRODUCTION}

The idea and practice of participation has developed since the 1960s, mainly due to research undertaken by Arnstein (1969). According to Reed (2008), its emergence was related to the criticism of technocratically understood modernization, the perceived weaknesses of planning, protests and social dissatisfaction, and the recognition of the role of local communities in decision-making. In Poland, the position of individual participation in environmental management is growing. After a period of large investments in environmental protection, mainly in industry, the time has come to tackle pollution related to diffuse sources. This mainly concerns air and water protection, and in this respect, Poland is far behind in relation to most EU countries. Only the conviction and involvement of individual users of the environment can bring the expected results, but the they are delayed in time. In the case of surface water, the problem has been gradually reduced, among others, through 
direct and agri-environmental subsidies under the Common Agricultural Policy of the EU (Czapiewska, 2017; Kołodziejczak, 2018; Jurgoński and Łowicki, 2020). On a local scale, the attitude of the inhabitants, anglers and tourists who use lakes for recreational purposes is very important (Bernaciak and Cichoń, 2012). The end of the 1990s, according to Sodulski (1999), showed that environmental problems during the transformation period were not solved neither by the system of orders and prohibitions, nor by market instruments, but to a large extent by the participation of residents.

Management of natural resources, which, according to Ostrom (1990), are often common and exhaustible, induces the local community to cooperate in the use of a given good. Particular importance is attached to local communities inhabiting regions whose development depends on ecosystems constituting their "natural capital". One such a region is the Szczecineckie Lakeland in Poland, where there are lakes of different ecological status. It was observed that lakes reduce not only their surface area, but also the level of services provided by these ecosystems' quality decreases (Bernaciak and Cichoń, 2012). The greater the pressure, the more the ecosystem is weakened (e.g., lack of selfcleaning processes), the less provisioning, regulating and cultural services it provides to the inhabitants as a consequence. Man, therefore, through irrational use of the environment, exposes valuable ecosystems to degradation (Bernaciak and Cichoń, 2012). Ecosystem degradation has a clear spatial representation in the volume of supply and demand for Ecosystem Services (ES) (Chen et al., 2019). This leads to increasing problems in lake management. It is a problem of bearing the costs of rehabilitation, securing bathing areas following sanitary standards, etc.

Managing lake ecosystems to increase the package of ecosystem services that are essential for recreation is necessary even when, according to Birgé et al. (2016), there is uncertainty about the system's response to management actions. This uncertainty, according to Paavola and Hubacek (2013), results from the fact that we still do not have full knowledge as to different types of governance structures, including participation levels, that influence ecosystems. Regardless of the difficulties resulting from the conflicting interests of stakeholders (Niedziałkowski et al., 2012), we can no longer imagine environmental management without participation, that is, participation for what is "common and public". A literature review by Brodie et al. (2009) shows that the term participation has three basic meanings. It is social (community) participation, and it concerns the participation of individuals in collective actions undertaken in the community in which they live daily. There is also public participation, where individuals engage in the activities of structures and institutions of a democratic state. The third meaning is individual participation, and covers the daily choices of an individual and may refer to, among other things, responsible consumption, financial support for activities or participation in social organizations. In the literature, we can find numerous methods of classification of participation (Arnstein, 1969; Renn, 2006; Reed, 2008) and approaches to the assessment of participation based on various models or assumptions (Basco-Carrera et al., 2017; Reed et al., 2013).
Matczak (2011) emphasizes, however, that participation is a relationship between the decision-making center (public authority) and the non-public sector (non-governmental organizations, unorganized citizens, public opinion, stakeholders, and others), and Ford et al. (2020) believes trust is key. The interests of communities and ecosystems are most often combined through the payment for ecosystem services (PES) incurred by users (Cichoń, 2019). Jones et al. (2020) believes that the theory behind the PES mechanisms must be updated to take into account more complex behavioral theories. Accordingly, in the 1980s, the concept emerged to take into account a wider range of sociological factors, including user behavioral factors (Leventhal and Scherer, 1987). In studies on agricultural issues, the characteristics of stakeholders/farmers may be such a determining factor for effective participation (Neef and Neubert, 2011; Shoyama and Yamagata, 2016).

This study aimed to define a set of respondents' features that may condition the specific model of participation. Referring to the classic proposition of Langton (1978), the most frequently mentioned features of citizens in the participation process are activity and involvement. Public activity consists of communityinitiated and controlled activities to influence government decisions. For Lubell (2002), participation is also a derivative of civic activity, close to social movements. In turn, citizen involvement means encouraging participation mainly in public consultations (Creighton, 2005). In assessing environmental policy, Fischer and Glenk (2011) take into account emotional involvement. In the mid-1990s, Thomas Webler (1995) proposed the criterion of community competence to assess participation. According to Webler (1995), the scope of competences is adequate knowledge that allows us to realistically and effectively participate in the decision-making process. Shoyama and Yamagata (2016) also write about the importance of knowing the local environment. The participation process can also be assessed in relation to religiosity, financial wealth, or knowledge of local political elites (Sobiesiak-Penszko and Kotnarowski, 2012). The effectiveness of participation is also determined by the ability to deal with difficulties related to defining one's preferences and their aggregation. On the other hand, Murdock et al. (2005) indicate that successful participation depends largely on the goodwill of the organizers of the process, and Rowe and Frewer (2005) state that it depends on communication. The effectiveness of participation results from the extent to which complete and adequate information is obtainable from all necessary sources, transmitted and absorbed by all interested parties, and processed to develop a consensus. In the management of ecosystem services, the willingness to pay for the use of ecosystem services becomes an important problem (Cichoń, 2019). More and more often the role of a volunteer and the willingness to devote one's time are mentioned (Haklay et al., 2018), therefore the importance of public participation geographic information system (PPGIS) should be emphasised (Jankowski, 2009; Czepkiewicz et al., 2016). Matczak (2011) also talks about the feeling of helplessness and the conviction of the public opinion that the authorities will make a decision anyway without considering the position of the citizens. In the participatory model, Coye and 
Belohlav (1995), Banasik (2015), and Chrzanowski and Rościszewska (2014) list four features that should characterise the local community. These include: involvement, attachment to the place of residence, creativity, and logical thinking skills. On the other hand, in the diagnosis of public participation in Poland prepared by Olech (2012), involvement resulting from gender, age, education, social status of an individual or attachment to the place of residence was emphasized. Factors that may influence pro-environmental involvement, including attitudes, comprehensively based on various models were presented by Kollmuss and Agyeman (2002).

Attitude is instead a general evaluative summary of the information derived from the affect, behavior, and cognition (Crites et al., 1994), and the object of the attitude in this article is a lake. So, to achieve the main goal of the study, we answered three basic research questions: 1) Which features dominate the attitudes of the respondents, especially concerning the development of lakeshore selected for recreation? 2) To what extent do the age groups of the respondents differ, taking into account the selected characteristics of the respondents and the factors determining the choice of a lake for recreation? 3) Which features correlate with the willingness to act and may condition the functioning of one of the four models proposed by Olech and Kaźmierczak (2011) among young people from the Szczecinecki District.

The analysis uses four models of public participation, proposed by Olech and Kaźmierczak (2011). The first model, asymmetric, assumes providing information to a nongovernmental party whose role is passive and which only acknowledges decisions made by the public sector. The second model, an opinion-making and consultation model, enables the feedback of citizens who can convey their comments and proposals to decision-makers. The third model, symmetric, is of a partnership nature, as it assumes active participation of citizens in the preparation of policies and decision-making. The fourth model is delegation, i.e., delegating authorizations to stakeholders to make decisions or actions independently.

\section{STUDY AREA}

The subject of the analysis are nine lakes in the Szczecinecki District in northern Poland (Figure 1).

According to the classification of ecoregions for rivers and lakes based on fauna living in European inland waters (EEA, 2020), the district is situated in the Central Plains ecoregion. The studied lakes are situated in the Oder River Basin District and the Warta Water Region. All lakes belong to the category of lakes with high calcium content, most of them with a low outflow from the catchment area. The three lakes Dołgie, Trzesiecko, and Wielimie, belong to lakes with a large outflow from the catchment area. The general condition of five lakes is assessed as bad, and four as good (aPGW database, 2020). All lakes have been designated as sensitive areas under Directive 91/271/EEC. Most of the lakes are natural. Only the Trzesiecko and Wielimie lakes have the status of being strongly changed due to changes in natural retention, unfavorable development of the shoreline zone (Lake Trzesiecko), a strong decrease water levels, and the related change in the dynamics of water levels and flows (Lake Wielimie). The land cover in the Szczecinecki District is of a

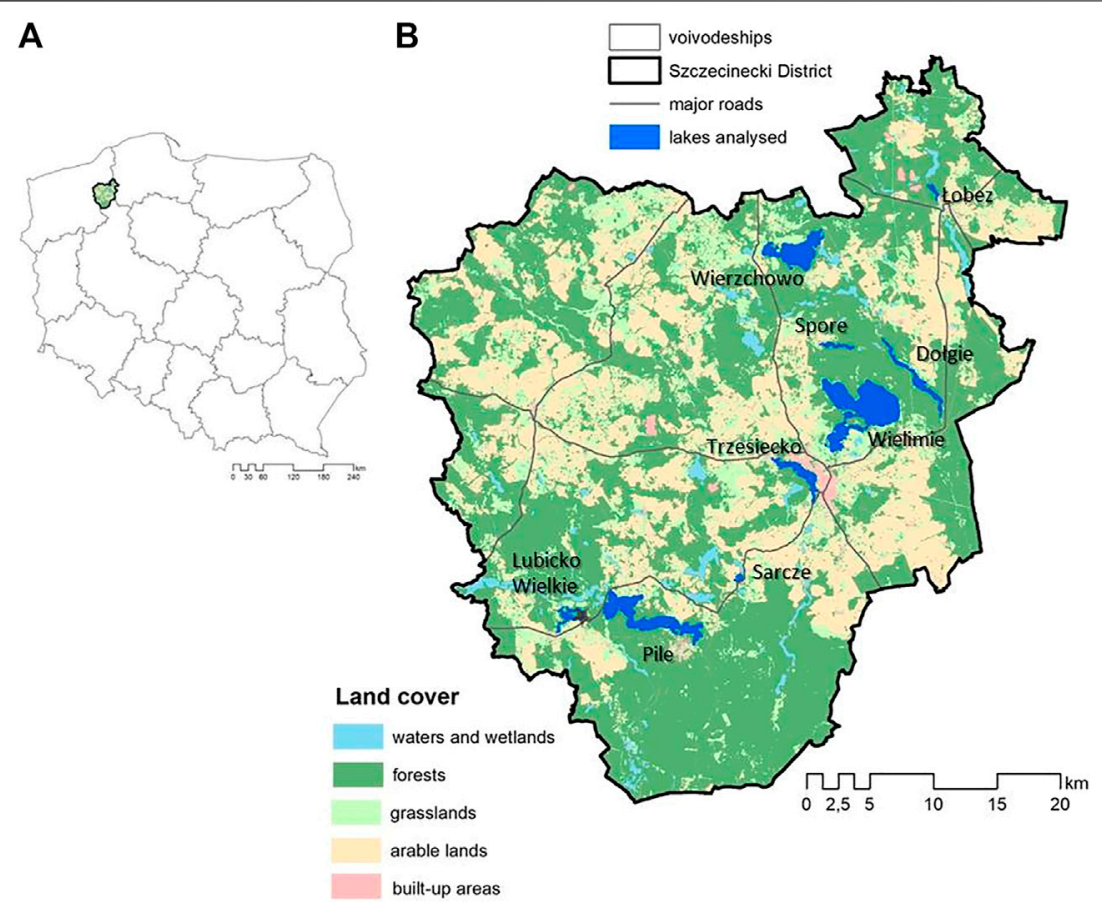

FIGURE 1 | Location of study area: (A) within Poland, (B) within the Szczecinecki District. 


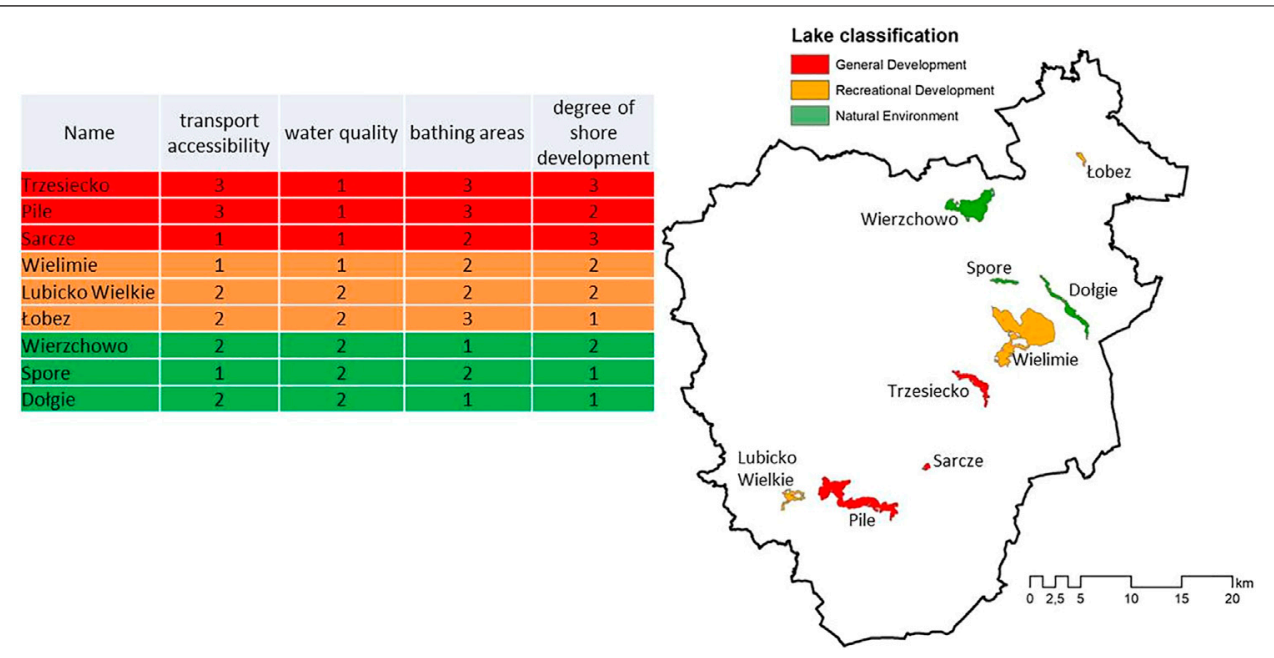

FIGURE 2 | Indexed scores based on transport accessibility, water quality bathing areas and degree of shore development for each category of lakes. Rates: 1 - low, 2 - medium, 3 - high.

particular forest and agricultural character. Forests cover more than half of the area, and arable land a quarter. The rich river and lake network covers almost $5 \%$ of the district's area, and the accompanying meadows cover about $15 \%$. The main threats to the lakes are farming with scattered buildings, as well as tourism and recreation.

\section{METHODOLOGY}

\section{Classification of Lakes Analyzed}

In order to assess the relationship between the attitude of young people and the types of lakes chosen by them for recreation, a classification of lakes was prepared. It takes into account road accessibility, water quality, number of bathing areas, and degree of shore development. The length of the main roads in a buffer of $1000 \mathrm{~m}$ around the lakes was assumed as the communication accessibility. The degree of shore development was calculated using the BDOT10K vector topographic map. On its basis, for each analyzed lake, the length of the shore zone occupied by individual land cover was calculated and multiplied by the weights indicating their development. These weights were: water and wetlands, forest and wooded areas, sandy or gravel areas (3), meadows (1), arable lands (-1), residential and commercial buildings (-2), industrial and traffic areas (-3). Data on bathing areas were obtained from GIS database (2020), and the quality of water come from aPGW database (2020). The water quality in lakes was assessed on the basis of data from the Environmental Monitoring System. According to Polish law (Regulation of the minister of the Environment, 2008), the final assessment includes two types of status classes: bad (no. One in Figure 2) and good (no. Two in Figure 2).

\section{Questionnaires}

In order to achieve the adopted goal of the study, it was assumed that the attitude consists of features related to the cognitive process, emotions and behavior (Crites et al., 1994). The cognitive element of the attitude is related to: 1) knowledge about lake ecosystems, 2) logical thinking, and 3) a belief in the effectiveness of actions taken by the municipal authorities. The emotional component consists of: 4) the desire to rest at the lake associated with the attractiveness of the lake, 5) attachment to the place of residence, and 6) sensitivity to the common good. In turn, the affective component includes: 7) creativity, 8) willingness to act, and 9) involvement in activities.

The questionnaires were conducted in 2015-2016 on a group of 180 people permanently living in the Szczecinecki District (Figure 3), of which 13 were not completed. Among all resting people at the lake, $70 \%$ are represented by those aged $15-24$. We assumed that the values of attitude features would be increasing with age, so the group was divided into two subgroups. The respondents aged 15-19 (92 persons-55\%) was youth studying in Poland in secondary school who completed the questionnaires in schools. The second group, people aged 20-24 (75 persons-45\%) was studying and professionally working youth who completed the questionnaires at the lakes. No correlation between the choice of the lake and the place of completing the surveys was found. It was an auditorium survey, and the respondents were selected randomly, but they had to be in the age group from 15 to 24 and permanently reside in the Szczecinecki District.

The subject of questionnaire research was examining the attitudes connected with the recreation at the lakes, whereby the term "recreation" was understood as all forms of recreation activities, both active or passive. However, the possibility of active recreation at the studied lakes is very limited and it is not very popular there due to limited facilities and equipment. A questionnaire divided into five parts was used. In the first part of the survey, young respondents specified the frequency of resting at a given lake and the factors determining the choice of a bathing area for recreation, as well as the attractiveness of selected lakes. The second part of the research included test tasks in the field of lake ecosystems functioning and ecosystem services. 
On this basis, the respondents' knowledge, logical thinking, and creativity were assessed. In the third part of the questionnaire, the students marked the statements they agreed with. Thanks to this, the emotional attitude of a student to the lakes and the conviction about the effectiveness of activities undertaken by the municipality were assessed. In the fourth stage, the degree of attachment to the place of residence, sensitivity to the common good and willingness to pay for the common good was determined based on the respondents' self-assessment. The assessment of the involvement of the respondents and willingness to act was influenced by their self-assessment and the description of activities undertaken in practice. All nine features were assigned points from 0 to 5 , with 45 points that could be obtained (Table 1). In the last part of the study, the respondent, based on a separate appendix, chose the most beautiful beach or bathing area from among the nine shown in the pictures (Figure 3). The survey also included questions about the personal characteristics of the participants, such as gender, age, education, net monthly salary, and place of residence.

\section{Data Analysis}

\section{Standardization of Data}

The data obtained from the surveys have been standardized for further analysis. The collected responses were used to define the characteristics of the respondents as indicated in Table 1. Seven out of the nine examined features (1-4 and 7-9) were transformed to a five-point scale, reflecting the answers to the questions. The size of a given feature is the sum of points awarded

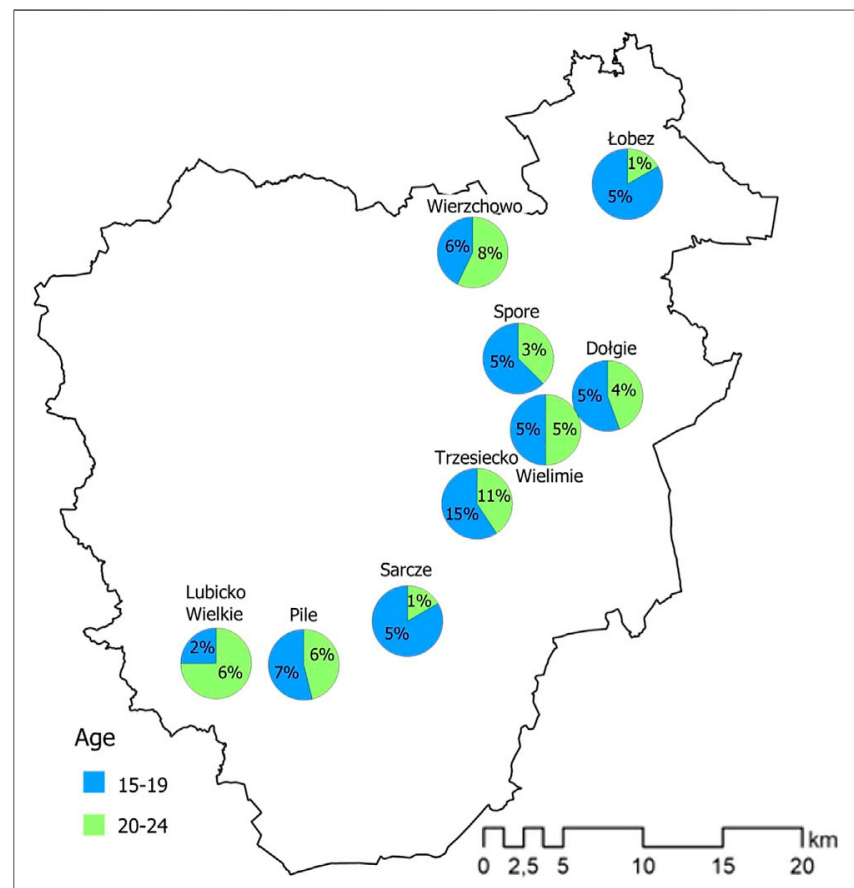

FIGURE 3 | Choosing a lake for recreation by respondents living in the Szczecinecki District in two age groups. Values represent the percentage of total respondents number. for answers to a given question or for solving a task. In the case of attachment to the place and sensitivity, the respondents made a self-assessment. For this analysis, the respondents were also grouped according to two criteria: age and the level of involvement in the decision-making process. Two age groups included respondents aged $15-19$ and 20-24. The next grouping range was carried out, taking into account the willingness of students to take action using the Jenks Natural Breaks Classification. The respondents were assigned to four groups: i) students whose involvement was assessed as lowest (score $=0$ ); ii) students with limited willingness to take action (score $=1-2$ ); iii) high-willingness students (score $=3$ ); and iv) the highest-rated willingness for students (score $=4-5$ ).

\section{Statistical Analysis}

The data collected as a result of the questionnaire survey was analyzed in terms of the assessment of differences between age groups and groups with different willingness to act. Two nonparametric tests were used here: the Mann-Whitney $U$ test for independent samples (for age groups), the Krusk-Wallis test (to compare the four groups of willingness to act) and the Wilcoxon test for dependent samples (to show the differences between the value of the pro-environmental attitudes in groups indicating different development types of lakes). The application of the indicated tests was preceded by the assessment of the normality of the distribution of individual variables using the Shapiro-Wilk test. The final results were also compared with the results of the correlation analysis between the variables, without taking into account the grouping of respondents, using the Spearman's rank correlation method.

\section{RESULTS}

\section{Types of Lakes}

Taking into account road accessibility, water quality, number of bathing areas, and degree of shore development, a classification of the studied lakes was created. Lakes Wierzchowo, Spore, and Dołgie are assigned to the Natural Environment (NE) lakes type (Figure 2). These are lakes that do not have much existing development or recreational use. Recreational Development (RD) lakes include the Wielimie, Lubicko Wielkie, and Łobez lakes. RD lakes are characterized by moderate levels of recreational use and existing development. General Development (GD) lakes are lakes of varying sizes and depths with high levels and mixes of existing development. This group includes lakes Trzesiecko, Pile, and Sarcze.

\section{Choosing a Lake for Recreation by Respondents}

Almost a third of all young respondents rest by the city's Lake Trzesiecko in the district capital (Figure 3). Nearly 50\% of the respondents rest at the most developed lakes (GD type on Figure 2), and $24 \%$ of young respondents rest by three recreational lakes ( $\mathrm{RD}$ type on Figure 2), with Lake Łobez having the most sustainable management in this subgroup, for 
TABLE 1 | Questions and instructions included in the questionnaire assigned to nine selected features.

$\begin{array}{lcc}\text { Component of a } & \text { Tested features } & \text { Instructions/questions in the } \\ \text { pro-environmental } & \text { questionnaire } \\ \text { attitude } & \end{array}$

Cognitive

1. Knowledge

2. Logical thinking

3. Belief in the effectiveness of actions taken

Affective

4. Desire to rest at the lake

8. Willingness to act

9. Involvement in activities

7. Creativity
1. Expand the abbreviation SzLOT (szczecinek local tourist organization)
2. Explain what sustainable development means
3. From three answers, select what eutrophic lake' means
4. Select from among three answers what is the reclamation of lake trzesiecko is
5. From among the three answers, select the reason for algal blooms
6. Select from three answers what is causing the eutrophication of lakes
7. From three responses, mark the rate of lake water pollution over the past decade
8. Select from three answers what causes cyanobacteria in lake waters
9. From three answers, mark how the lake water level has changed over the decade
10. Mark whether the development of szczecinek depends on the purity of water

11. Specify whether you are convinced that city development depends on proper lake management

12. Specify whether you are convinced that the actions taken by the municipality are effective

13. Specify whether you are convinced that the lake reclamation projects undertaken (jet ski lift, aerator) are improving the quality of the lake water

14. Specify if you are convinced that even the smallest action contributes to lake protection, including introducing beach fees

15. Specify whether you are convinced that it is worth improving the quality of lake ecosystems, even at the cost of creating new jobs

16. Assess to what extent you like relaxing by the lake

17. Specify how often you rest by the lake

18. Assess how long you spend relaxing by the lake

19. Assess to what extent the surroundings (landscape, land use, microclimate) are attractive

20. Assess to what extent the development of the lake (beach) shore is attractive

5. Attachment to the place of residence 21-25. Assess your degree of attachment to where you live (5 is strong attachment)

6. Sensitivity to the common good 26-30. Rate your level of sensitivity to lake pollution as a common good (5 is highly sensitive)

31. Suggest a valuation of the benefits of the lake to some economic entity

32. Give an example to what extent the municipality can benefit from the presence of a lake

33. Give an example to what extent an individual can benefit from the presence of a lake

34. Suggest what actions can protect the lakeshore

35. Suggest what actions can protect the lake water

36. Specify if you are ready to pay for the use of the beach/lake if it results in an improvement in their ecological, sanitary and aesthetic condition

37. Specify if you are ready to pay for the use of the beach/lake if it results in better shore development 38. Specify if you are ready to participate in social actions to improve the condition of the lake ecosystem

39. Specify what activities you are ready to participate in (participation in public consultations, paying taxes)

40. Specify what activities you are ready to participate in (participation in NGOs, protest)

41. Specify your level of environmental involvement

42. Assess whether you are taking actions to protect lakes

43. Check if you are a member of any association or foundation dealing with the environmental protection

44. Specify how often you point out to others that they are polluting the lake

45. Specify how often you point out to others that they are polluting the beach whom the best water quality and natural character of the shores are noted, and at the same time, the best-developed bathing area. Thirty-one per cent of the respondents rest by natural lakes (NE type on Figure 2).

\section{Features Dominant in the Respondents' Attitude in Relation to Nine Selected Lakes} The attitude of young residents of the Szczecinecki District is dominated by the emotional component, with the most important factor being the will to rest by the lake (average 3.6/5.0 points) and attachment to the place of residence (average $2.96 / 5$ points) (Table 2). Almost $70 \%$ of respondents like to relax by the lakes. Not without significance, although at a lower level, is sensitivity to the common good. People with high values for the affective component prefer natural lakes, while those with low emotionality choose recreational lakes located in agricultural catchments.

The second component shaping the attitudes of the respondents consists of cognitive elements. An important role is played by the conviction about the effectiveness of actions taken by the commune (average 2.84/5 points). Every second respondent is convinced that municipal development depends on the purity of lakes and proper lake management, and every fourth respondent is convinced that the actions taken by the municipality for the benefit of lake ecosystems are correct. For 
TABLE 2 | Average values of respondents' features compared to the lakes selected by the respondents.

\begin{tabular}{|c|c|c|c|c|c|c|c|c|c|c|}
\hline \multirow[t]{2}{*}{ Feature } & \multicolumn{3}{|c|}{ General development } & \multicolumn{3}{|c|}{ Recreational development } & \multicolumn{3}{|c|}{ Natural environment } & \multirow[t]{2}{*}{ Mean } \\
\hline & Trzesiecko & Pile & Sarcze & Wielimie & Lubicko & Łobez & Wierzchowo & Spore & Dołgie & \\
\hline Knowledge & 2.18 & 2.38 & 2.57 & 1.85 & 1.99 & 1.92 & 1.88 & 3.06 & 1.85 & 2.18 \\
\hline Logical thinking & 2.42 & 3.05 & 2.89 & 1.57 & 2.77 & 2.57 & 2.75 & 3.12 & 3.0 & 2.68 \\
\hline Belief in the effectiveness of actions taken & 3.32 & 2.66 & 3.17 & 2.21 & 2.94 & 2.78 & 2.78 & 2.75 & 3.04 & 2.84 \\
\hline Desire to rest at the lake & 3.60 & 3.33 & 4.92 & 3.85 & 3.61 & 3.14 & 3.97 & 3.75 & 4.59 & 3.61 \\
\hline Attachment to the place of residence & 3.10 & 2.77 & 2.92 & 2.71 & 2.99 & 2.28 & 3.10 & 3.18 & 3.61 & 2.96 \\
\hline Sensitivity to the common good & 2.44 & 2.44 & 1.78 & 2.0 & 2.10 & 2.85 & 2.61 & 2.31 & 2.59 & 2.34 \\
\hline Creativity & 2.61 & 2.16 & 3.21 & 2.07 & 2.72 & 1.35 & 3.10 & 2.75 & 1.89 & 2.42 \\
\hline Willingness to act & 2.03 & 1.55 & 2.10 & 1.28 & 1.99 & 1.64 & 2.39 & 2.06 & 1.52 & 1.84 \\
\hline Involvement in activities & 1.56 & 1.27 & 1.75 & 0.99 & 1.16 & 1.35 & 1.42 & 1.31 & 1.39 & 1.35 \\
\hline Mean & 2.58 & 2.40 & 2.81 & 2.05 & 2.47 & 2.20 & 2.66 & 2.69 & 2.60 & \\
\hline
\end{tabular}

example, $43 \%$ of young respondents believe that it is worth improving the quality of lake ecosystems, even at the cost of creating new jobs. The most convinced ones chose Trzesiecko and Sarcze lakes to relax, i.e., developed lakes, but with lowquality lake water. In the cognitive component of the attitudes of young inhabitants of the Szczecinecki District, the skill of logical thinking was better than theoretical knowledge. Almost $22 \%$ of the respondents have no problem with drawing conclusions, and $16 \%$ of the respondents can boast of a good and very good level of knowledge. For example, $60 \%$ of respondents know that the presence of cyanobacteria in a lake is the result of an increase in the amount of nutrients, but only $50 \%$ believe that the increase in nutrients is due to human activity. In turn, what sustainable development means was explained by $12 \%$ of respondents. However, it is noticed that people with the highest knowledge about the functioning of ecosystems rest at Lake Spore, classified as a natural lake.

The third component of attitude is action, which relates to creativity at the average level of $2.42 / 5$ points. Every third respondent is characterized by high creativity. The willingness to act and involvement had the lowest average among the respondents. It is true that $30 \%$ of respondents declare that they do not pollute beaches or water, but also do not feel the need to point out to someone that they are polluting. Over $60 \%$ of young residents support ecological actions, such as "Cleaning up the world", but only $50 \%$ are ready to participate in it. The situation is even worse in terms of financial participation; only $13 \%$ would be willing to pay for the use of the beach and swimming in the lake. People with relatively high values for the behavioral component chose both urban and natural lakes for recreation, and those with a low level of this feature chose lakes with a different degree of development, but that was generally polluted.

The Wilcoxon test for dependent samples $(p<0.05)$ shows significant differences between the values of the proenvironmental attitudes in groups of respondents indicating different types of lake development. The lowest rated respondents were in the group indicating Recreational Development Lakes. Their overall mean score (6.74) is lower than that in the group indicating General Development Lakes (7.8) and Natural Environment Lakes (7.97). A good example in this group is Wielimie Lake. It was indicated as a favorite by

TABLE 3 | Summary of medians of individual variables in two analyzed age groups.

\section{Feature}

Natural factors determining the choice of a lake

Natural factors determining the attractiveness of the lake

Non-natural factors that determine the attractiveness of the lake

Assessment of the attractiveness of the lake (related to emotions)

Desire to rest at the lake

Attachment to the place of residence

Sensitivity to the common good

Knowledge

Logical thinking

Creativity

Involvement in activities

Willingness to act

The amount that students are willing to spend on entry to the beach

$\begin{array}{cc}\text { Age } \mathbf{1 5 - 1 9} & \text { Age }>\mathbf{1 9} \\ \mathbf{2 . 5 0} & \mathbf{1 . 5 0} \\ 3.35 & 3.15 \\ 2.85 & 2.95 \\ 2.18 & 2.10 \\ 3.00 & 3.00 \\ \mathbf{3 . 5 0} & \mathbf{2 . 5 0} \\ 2.35 & 2.25 \\ 2.00 & 2.00 \\ 2.95 & 2.9 \\ 2.40 & 2.40 \\ \mathbf{1 . 5 0} & \mathbf{1 . 0 0} \\ \mathbf{2 . 5 0} & \mathbf{2 . 0 0} \\ 6.50 & 5.50\end{array}$

Statistically significant differences are shown in bold. 
almost half of the respondents and this group has the lowest average rate for nine features (2.05/5 points).

\section{Characteristics of Age Groups in Terms of the Analyzed Features and Factors Determining the Choice of a Lake for Recreation}

Analyses of differences between the age groups for the selected nine features showed statistically significant differences $(p>$ 0.05 ) in terms of four analyzed features: attachment to the place of residence, creativity, willingness to act, and involvement in activities (Table 3). The identified features made it possible to characterize these groups.

The common feature of both groups is a similar level of knowledge and logic, as well as the belief in the effectiveness of actions taken by decision-makers. The group aged 15-19 is characterized by significantly greater attachment to the place of residence and higher creativity. The respondents of this group are also characterized by a greater willingness to pay and involvement in activities than the older group. There are also statistically significant differences between age groups in terms of the factors determining the choice of a lake for recreation. The group of younger respondents in the decision-making process about choosing a lake for recreation is more driven by natural factors, e.g., type of lake or landscape. Differently for the older group, the factors beyond natural are decisive, primarily the existing technical infrastructure. The respondents' lake choices (Figure 3), for both the younger and older groups, do not reflect the above statements.

\section{Features Conditioning the Participation Models}

Assuming that the respondents will manage lake ecosystems in a few years, the most important factor in the model of participation among people aged $15-24$ is readiness to act. According to this feature, the respondents were divided into four groups according to the by Olech and Kaźmierczak (2011) models, which differ in their readiness to act. These four groups were compared in terms of the possibility of statistically significant differences in the remaining assessed features. As a result of the conducted analyses, statistically significant ( $p$-value $>0.05$ ) differences were found in the following areas: desire to rest at the lake, belief in the effectiveness of actions taken, knowledge, logic, and creativity (Table 4).

Figure 4 presents the range of features characteristic for each participation model and a model representing the features of respondents. According to the information presented, the highest values of all individual features are characteristic for the delegation model, which reflects the high involvement of the community in environmental management. The lowest values, on the other hand, are the same as the asymmetric model in which local communities show less involvement.
The values for the other two models-symmetric and consultative-oscillate around similar values, with a higher rating in terms of desire to rest at the lake and creativity is characteristic for the symmetric model, while higher values in terms of belief, knowledge and logical thinking may accompany communities operating in the consultative model. The above results indicate that the assessment of the feasibility of individual models should include all the presented features, and their values should be analyzed jointly.

Joint analysis of the respondents' features indicated that the studied group most likely exhibited features characteristic for the consultative model. Most of the respondents exhibited the characteristics of the consultative (36.3\%) and symmetrical model (40\%). However, it is worth recalling that for these two models, the respondents only selected features that exactly match the model. The delegation model is characteristic of $3 \%$ of the respondents, and the asymmetric model, $20.8 \%$.

\section{DISCUSSION}

Public participation is widely recognized as a critical aspect in a variety of public accountability, and environmental processes. Research and experience in this field have shown that public participation leads to better decisions and, by providing local or independent sources of information and examining alternative management strategies, it builds trust (Krishnaswamy, 2012). According to Wesselink et al. (2011), it is necessary to take a more critical look at the design of management systems that we still do not fully understand about the different levels of participation that affect ecosystems. However, to understand this and apply it in ES management, knowledge about stakeholders is required (Goldberg et al., 2018).

The emotional and sensitivity elements dominate the attitude of young inhabitants of the Szczecinecki District. The social diagnosis in the field of sensitivity to the common good have shown a positive trend in Poles for several years (Czapiński and Panek, 2011). It is worth emphasizing, however, that this diagnosis does not take into account sensitivity to the environment. Respondents who are characterized by low sensitivity to the common good and do not show attachment and willingness to rest by the lake choose lakes close to their place of residence, which are intensively developed, but with low water quality. Such a choice of lakes for recreation is not fully rational and understandable. According to Leszczyńska (2016), differences in individual behaviors may explain the emotional state of an individual. The conducted research has shown that it is impossible to rationally explain decisions without taking into account intuitive and emotional factors (Lerner et al., 2004). Different conclusions were presented by Dietrich (2013), who stated that emotions do not change pro-environmental behaviour, but that a pro-environmental attitude is important in predicting behavioural intentions. 
TABLE 4 | The means and medians for the features determining the individual participation models.

\begin{tabular}{|c|c|c|c|c|c|c|c|c|c|c|}
\hline \multirow[t]{2}{*}{ Model } & \multicolumn{2}{|c|}{$\begin{array}{c}\text { Desire to rest at the } \\
\text { lake }\end{array}$} & \multicolumn{2}{|c|}{$\begin{array}{c}\text { Belief in the } \\
\text { effectiveness of } \\
\text { actions taken }\end{array}$} & \multicolumn{2}{|c|}{ Knowledge } & \multicolumn{2}{|c|}{ Logical thinking } & \multicolumn{2}{|c|}{ Creativity } \\
\hline & Mean & Median & Mean & Median & Mean & Median & Mean & Median & Mean & Median \\
\hline Asymmetrical & 3.34 & 3.00 & 2.23 & 2.00 & 1.46 & 1.00 & 2.03 & 2.00 & 1.94 & 2.00 \\
\hline Consultative & 3.95 & 4.00 & 3.12 & 3.00 & 2.26 & 2.00 & 2.72 & 3.00 & 2.31 & 2.00 \\
\hline Symmetrical & 4.34 & 5.00 & 2.87 & 3.00 & 2.18 & 2.00 & 2.73 & 3.00 & 2.57 & 2.00 \\
\hline Delegation & 4.40 & 5.00 & 3.20 & 3.00 & 3.00 & 3.00 & 3.00 & 3.00 & 4.60 & 5.00 \\
\hline
\end{tabular}

The cognitive component, including knowledge and creativity, exhibited a lower level, which may mean that formal education has failed to some extent. Literature analysis shows that formal education aimed at acquiring knowledge and meeting the requirements of the national curriculum "kills creativity" (Kaila, 2005). Shaheen (2010) shows that creativity is a "global phenomenon" and there are many practical ways for it to become part of an educational program. An interesting solution may be the use of the LiNCAGES information platform presented by Linney et al. (2020). An alternative for young people from the Szczecinecki District can be informal education conducted by the Szczecinek Local Tourist Organization. It is a pity that only $17 \%$ of respondents can develop the abbreviation of this organization. Young respondents are also unable to explain the term "sustainable development", although many examples in geographic education at the secondary school level refer to such development (Ministry of National Education Regulation of January 30, 2018). A similar situation occurs with the understanding of the term reclamation. Only every third respondent knows what it is. This is a surprise, because the issue of reclamation frequently appears in the media in Szczecinek, due to the presence of Trzesiecko Lake, which has been undergoing reclamation since 2004 .

The study showed that the higher the level of knowledge about ecosystems, the more often respondents choose natural lakes. On the other hand, the lower the value of this cognitive

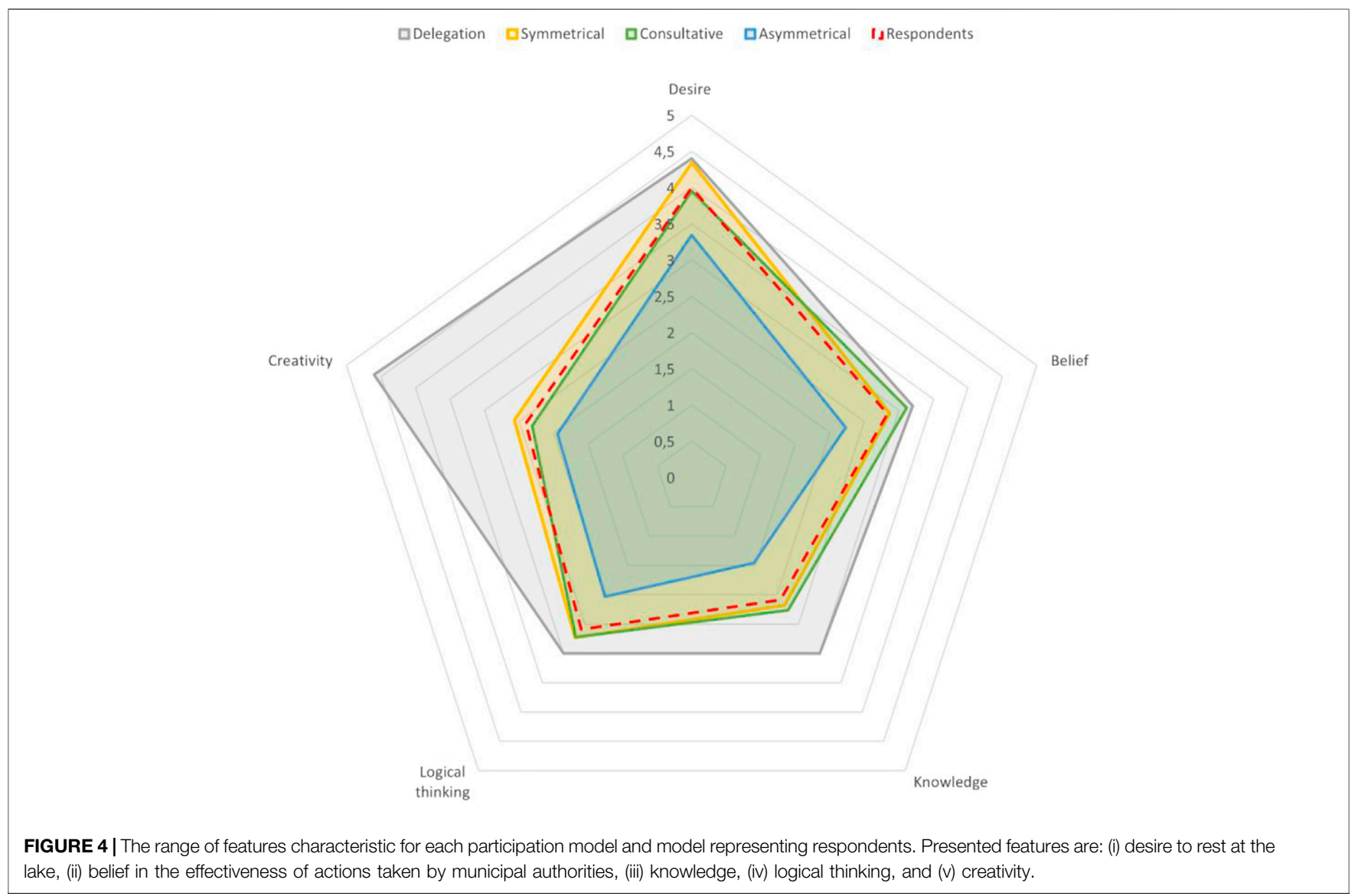


component in the attitude, the more often recreational lakes were chosen, and the decision to choose for recreation results from individual needs, most often related to the development of lakes or water quality. This is confirmed by the research of Jeon et al. (2005), which showed that the knowledge of the physico-chemical parameters of water influences the choice of a lake for recreation. Knowledge about the ecosystems influences the perception and understanding of reality, and thus the judgments and decisions made. This was pointed out by Dupont et al. (2015) in studies of landscape perception by experts and layman, emphasizing how important these results are for participatory landscape management. Apart from knowledge, a large role is assigned to beliefs (Kaiser et al., 2005). It was noticed that regardless of the level of belief in the rightness of the actions taken by the commune, the respondents choose both natural and transformed lakes. The younger group pays more attention to natural factors, and the older ones to non-natural factors. As you can see, the declarations regarding the choice of a lake for recreation do not confirm the actual decisions of the respondents. The results indicate that for a young person aged 15-19 (at the decision level) or 20-24 (at the declaration level), the most valuable are places focused on utility.

Not without significance, albeit at a much lower level, are the values of the behavioral component. Feldman et al. (2010) surveyed young Americans aged 18-34 and also noted the low involvement. In their view, there has been a sharp increase in the number of young people politically engaged in climate action, but this has not (yet) translated into the entire age group. In the opinion of Pietras and Myga-Piatek (2005), taking actions aimed at solving an environmental problem appears only when an unacceptable, burdensome object, disturbing the spatial order and causing controversy is found in the immediate vicinity. This is when the community gets involved because there is a public concern and/or need (Creighton, 2005) and/or citizens will want to pursue their interests (Arnstein, 1969). Such an example may be the participation activities of the inhabitants of Szczecinek to limit the activity of the Kronospan plant, which, by producing chipboards, pollutes the air and water. This situation actually motivates the municipality to take action to improve air quality, although in the opinion of Olech (2012), compared to the rest of Poland, the inhabitants of this region are the least likely to look for information about the possibility of participation and cooperate with the authorities in the preparation of draft resolutions the least frequently. The inhabitants of Szczecinek, however, are fighting to a much lesser extent for the polluted Wielimie Lake or Trzesiecko Lake, located near the Kronospan company, which explains the smallest involvement in lakes protection.

It was noticed that the groups differ in willingness to act and undertake actions; however, it should be emphasized that in both groups, the above characteristics are at a low level. The research conducted by Cichon (2008) confirms the fact that in the hierarchy of values for people aged 15-17, the environment comes last, which makes it difficult to shape responsibility for ecosystems. According to Kowalik (2006), there is no affirmative approach, assuming that the environmental values of the place of residence may be a value in itself, creating "natural capital". According to Mizgajski (2010), the attitude towards nature of modern man is shaped by economic arguments. Young people treat the lake's ecosystem very pragmatically, but the hope is that over time the need for cooperation will arise, because, as stated Kagan (2020), 35\% of the variability in the will to act can be explained by age. At the moment, however, the willingness to act seems to be more important, which is at an average level. This willingness to act, also expressed in the willingness to pay for relaxing on the beach, is greater among younger respondents who are also more attached. This is confirmed by the research conducted by Cichon (2019). Research conducted by Bernaciak and Cichoń (2013) and Cichoń (2019) also indicate that young people are ready to pay more for such a ticket than older people, but also that the declared value increases year by year. The Nielsen Global Corporate Sustainability Report (2015) shows that among those under 20, the percentage of willingness to pay for sustainability increased from 55\% of all respondents in 2014 to $72 \%$ in 2015 . On the other hand, we have a neuroimaging study conducted by Sawe and Knutson (2015), where it was found that the material support of resources is determined by negative emotions, e.g., indignation at environmental degradation. Interestingly, research by Sargisson et al. (2020) on a group of 11,820 participants from seven European countries, did not confirm the relationship between socio-demographic variables and environmental values.

It seems right to say that it may be important to combine high willingness to act with other characteristics of stakeholders, as indicated by the presented results, i.e., with knowledge, logical thinking, belief in the effectiveness of actions taken, and additionally with creativity and desire to rest at the lake. If we compare it with the participatory models presented by Coye and Belohlav (1995), Banasik (2015), Chrzanowski and Rościszewska (2014), two of the five characteristics of the respondents repeat themselves, namely creativity and the ability to think logically. Thus, cognitive elements and creativity regain significance in participation, although at a higher level only in the delegation model of participation. Without knowledge and an innovative approach, it is difficult to manage lake ecosystems effectively. However, the importance of knowledge in the process of participation, cannot be overestimated, because, as stated Matczak et al. (2015), the participants entering the participatory process have limited knowledge and do not have firmly established beliefs. This means that at the beginning they do not have knowledge, but if they represent the delegation model, they should already have this knowledge, as well as being ready to act, or willing to rest by the lake. According to Isen et al. (1985), these three features are correlated with each other, and such an attitude is characteristic of $3 \%$ of the respondents. The respondents do not differ from European communities in this respect (European Commission Report, 2008). 
Taking into account European and American tendencies, the perspective of participatory management of lakes in the Szczecineckie Lakeland seems to be moderately optimistic, as most of the respondents represent symmetric and consultative models resulting from average level of logic, conviction and willingness to act. One of the activities that can help in management is, according to Goldman and Tallis (2009), supporting education. However, when looking at the presented results, it should be born in mind, that education by increasing only cognitive components, does not go hand in hand with the motivation to participate (Choudhury, 2014).

\section{CONCLUSION}

In areas such as the Szczecinecki District, where both the potential and demand for ecosystem services are very high, young people should be properly prepared to participate in environmental management. On the level of effective communication between the authorities and the local community, according to Goldberg et al. (2018), understanding the individual attitudes and beliefs of stakeholders is crucial. Proper preparation of stakeholders, by supporting pro-environmental attitudes, is the key of importance. Hence, the challenge, both on a local and global scale, is to educate a competent and creative person, convinced of the need to act for the common good, who will become ready to take action over time.

To achieve this goal, it is worth considering two solutions. The first is the concept of social learning. Webler et al. (1995) proved that for participatory projects to be successful, honesty and competence are necessary, as well as a space in which citizens gain knowledge (Garmendia and Stagl, 2010). It is also a kind of mechanism leading to moral development, which allows you to overcome selfishness and care only for your interests and deal with uncertainty. According to Matczak (2011), the idea of social learning is closely related to the problem of sustainable development. The second solution is the use of modern forms of communication. According to Jenkins et al. (2009), a new participatory model of culture was created, characterized by low civic involvement, but with strong support for creativity and sharing one's creativity with others. Communication tools, such as discussion groups, ensure that public consultations and discussion panels are held, as well as the creation of active interest groups and so-called smart mobs. According to Peisert and Stachura (2011), e-mobilization is an important dimension of participation because it creates the possibility of bottom-up organization, e.g., based on interactive maps (Młodkowski et al., 2016; Jankowski et al., 2017). According to Haklay et al. (2018), public participation in spatial planning allows the development of tools under PPGIS, Geoweb, and geographic volunteering (VGI).

Thanks to these solutions, it is possible to shape attitudes based on all five features, while the set of stakeholder features is one of the components of the functioning of participatory models. It is worth emphasizing that every concept of education should include not only knowledge, but also creativity, attachment to little homeland and sensitivity. The combination of these attitude features with values and emotional involvement, Kollmuss and Agyeman (2002) called "pro-ecological awareness". Education creating the development of ecological awareness, will be leading up to protection of lakes, through making choices for common good, not individual one. This combination is embedded in broader personal values and shaped by personality traits, both internal and external. This confirms that we have dualism in ES management and participation, where we combine rational and effective features. While in economic models the assumption of the separability of the cognitive and emotional dimensions is a source of controversy (Leventhal and Scherer, 1987), in participation models it should be the basic methodological assumption. However, due to the complexity of the influence of particular features on functioning in a particular model, further research is needed. For example, it would be very interesting to check how the possibilities of active recreation by the lake (jogging or walking along the shore, kayaking, motor boating) influence the decisions of young people.

\section{DATA AVAILABILITY STATEMENT}

The raw data supporting the conclusion of this article will be made available by the authors, without undue reservation.

\section{ETHICS STATEMENT}

Ethical review and approval was not required for the study on human participants in accordance with the local legislation and institutional requirements. Written informed consent from the participants' legal guardian/next of kin was not required to participate in this study in accordance with the national legislation and the institutional requirements.

\section{AUTHOR CONTRIBUTIONS}

MC-preparation of the concept of the article, conducting survey research, preparation of quantitative data for statistical analyzes, discussion of the results obtained, writing an article WW-statistical data analysis, description of the methodology for statistical analyzes, preparation of figures, discussion of the results obtained, internal review of the article DŁ-developing the classification of lakes, writing of the research area chapter, analysis of the literature on the research area, discussion of the results obtained, internal review of the article, preparation of figures, translation, preparation of the text for publication. 


\section{REFERENCES}

aPGW database. (2020). National Water Management Holding Polish Waters. https://www.apgw.gov.pl/pl/II-cykl-materialy-do-pobrania.

Arnstein, S. R. (1969). A Ladder of Citizen Participation. J. Am. Inst. Planners 35 (4), 216-224. doi:10.1080/01944366908977225

Banasik, P. (2015). Zarządzanie Partycypacyjne Czy Imperatywne Władztwo W Wymiarze Sprawiedliwości (Participative Management or Imperative Reign in the justice System). Manag. Sci. 4 (25), 9-27.

Basco-Carrera, L., Warren, A., van Beek, E., Jonoski, A., and Giardino, A. (2017). Collaborative Modelling or Participatory Modelling? A Framework for Water Resources Management. Environ. Model. Softw. 91, 95-110. doi:10.1016/j. envsoft.2017.01.014

Bernaciak, A., and Cichoń, M. (2012). Ecosystem Services' Changes Caused by Human Pressure (Case of the Lakes of Middle Pomerania, Poland). Ekonomia $i$ Środowisko 2 (42), 190-199. doi:10.34659/2019/3/39

Bernaciak, A., and Cichoń, M. (2013). Wartość Przyrodnicza Ekosystemów a Wycena Wartości Ekonomicznej Na Przykładzie Jezior Pomorza Środkowego. Res. Pap. Wrocław Univ. Econ. 317, 240-249. doi:10.15611/pn.2013.317.22

Birgé, H. E., Allen, C. R., Garmestani, A. S., and Pope, K. L. (2016). Adaptive Management for Ecosystem Services. J. Environ. Manage. 183, 1-10. doi:10. 1016/j.jenvman.2016.07.054

Brodie, E., Cowling, E., Nissen, N., Paine, A. E., Jochum, V., and Warburton, D. (2009). Understanding Participation: A Literature Review. London: National Council for Voluntary Organisations.

Chen, J., Jiang, B., Bai, Y., Xu, X., and Alatalo, J. M. (2019). Quantifying Ecosystem Services Supply and Demand Shortfalls and Mismatches for Management Optimisation. Sci. Total Environ. 650, 1426-1439. doi:10.1016/j.scitotenv. 2018.09.126

Choudhury, B. (2014). Positive Attitude towards Environmental Conservation: The Role of Secondary Education. Indian J. Positive Psychol. 5 (4), 407-410. doi:10.15614/ijpp.v5i4.1220

Chrzanowski, O., and Rościszewska, E. (2014). Zarządzanie Partycypacyjne. Angażowanie Społeczności, Zeszyt Partycypacji Publicznej. 1-2/2014. Warszawa: FISE.

Cichoń, M. (2008). "Społeczność Małego Miasta Wobec Lokalnych Wyzwań Ekologicznych (Na Przykładzie Miasta Murowana Goślina W Wielkopolsce)," in Zarzadzanie Krajobrazem Kulturowym I Kształtowanie Społecznych Postaw Proekologicznych (Streszczenia). Editors J. Konopacki and A. Skrzyńska (Gliwice: Jacek Skalmierski's Komputer Laboratory, Kraków-Sosnowiec-Niepołomice), 35-37.

Cichoń, M. (2019). Valuation of lake Ecosystems of Central Pomerania by Young People Using the Contingent Valuation Method. Ekonomia i Środowisko 3, 130-139. doi:10.34659/2019/3/39

Coye, R. W., and Belohlav, J. A. (1995). An Exploratory Analysis of Employee Participation. Group Organ. Manag. 20 (1), 4-17. doi:10.1177/1059601195201002

Creighton, J. L. (2005). The Public Participation Handbook. San Francisco: JosseyBass.

Crites, S. L., Jr., Fabrigar, L. R., and Petty, R. E. (1994). Measuring the Affective and Cognitive Properties of Attitudes: Conceptual and Methodological Issues. Pers Soc. Psychol. Bull. 20, 619-634. doi:10.1177/0146167294206001

Czapiewska, G. (2017). The Agri-Environmental Program in the Development of Agricultural and Rural Areas of the Pomorze Region. J. Agribus. Rural Dev. 16 (3), 519-529. doi:10.17306/j.jard.2017.00372

Czapiński, J., and Panek, T. (2011). (red). Diagnoza Społeczna 2011 - Raport, Warsaw, 271. http://www.diagnoza.com/pliki/raporty/Diagnoza_raport_ 2011.pdf.

Czepkiewicz, M., Brudka, C., Jankowski, P., Kaczmarek, T., Zwoliński, Z, Mikuła, Ł., et al. (2016). Public Participation GIS for Sustainable Urban Mobility Planning: Methods, Applications and Challenges. Rozwój Regionalny $i$ Polityka Regionalna 35, 9-35.

Dietrich, H. (2013). “The Role of Emotion in Environmental Decision Making,". Theses, Dissertations, and Student Research (Lincoln: Department of Psychology). https://digitalcommons.unl.edu/psychdiss/55.

Dupont, L., Antrop, M., and Van Eetvelde, V. (2015). Does Landscape Related Expertise Influence the Visual Perception of Landscape Photographs? Implications for Participatory Landscape Planning and Management.
Landscape Urban Plann. 141, 68-77. doi:10.1016/j.landurbplan.2015. 05.003

EEA (2020). Ecoregions for Rivers and Lakes. https://data.europa.eu/data/datasets/ data_ecoregions-for-rivers-and-lakes?locale=pl (Accessed January 12, 2021).

European Commision Report (2008). Attitudes of European Citizens towards the environment European Commission, 75. https://ec.europa.eu/commfrontoffice/ publicopinion/archives/ebs/ebs_295_en.pdf.

Feldman, L., Nisbet, M. C., Leiserowitz, A., and Maibach, E. (2010). The Climate Change Generation? Survey Analysis of the Perceptions and Beliefs of Young Americans. Washington: George Mason University Center for Climate Change Communication and Yale Project on Climate Change Communication. http://environment.yale.edu/ climate-communication-OFF/files/YouthJan2010.pdf.

Fischer, A., and Glenk, K. (2011). One Model Fits All? - on the Moderating Role of Emotional Engagement and Confusion in the Elicitation of Preferences for Climate Change Adaptation Policies. Ecol. Econ. 70, 1178-1188. doi:10.1016/j. ecolecon.2011.01.014

Ford, J. K., Riley, S. J., Lauricella, T. K., and Van Fossen, J. A. (2020). Factors Affecting Trust Among Natural Resources Stakeholders, Partners, and Strategic Alliance Members: A Meta-Analytic Investigation. Front. Commun. 5, 9. doi:10. 3389/fcomm.2020.00009

Garmendia, E., and Stagl, S. (2010). Public Participation for Sustainability and Social Learning: Concepts and Lessons from Three Case Studies in Europe. Ecol. Econ. 69 (8), 1712-1722. doi:10.1016/j.ecolecon.2010.03.027

GIS database (2020). Chief Sanitary Inspectorate. Bathing Service. https://sk.gis.gov. pl/ (Accessed March 15, 2021).

Goldberg, J. A., Marshall, N. A., Birtles, A., Case, P., Curnock, M. I., and Gurney, G. G. (2018). On the Relationship between Attitudes and Environmental Behaviors of Key Great Barrier Reef User Groups. Ecol. Soc. 23 (2), 19. doi:10.5751/es-10048-230219

Goldman, R. L., and Tallis, H. (2009). A Critical Analysis of Ecosystem Services as a Tool in Conservation Projects. Ann. N Y Acad. Sci. 1162, 63-78. doi:10.1111/j. 1749-6632.2009.04151.x

Haklay, M., Jankowski, P., and Zwoliński, Z. (2018). Selected Modern Methods and Tools for Public Participation in Urban Planning - A Review. Quaestiones Geographicae 37 (3), 127-149. doi:10.2478/quageo-2018-0030

Isen, A. M., Johnson, M. M. S., Mertz, E., and Robinson, G. F. (1985). The Influence of Positive Affect on the Unusualness of Word Associations. J. Personal. Soc. Psychol. 48 (6), 1413-1426. doi:10.1037/0022-3514.48.6.1413

Jankowski, P., Czepkiewicz, M., Młodkowski, M., Zwoliński, Z., and Wójcicki, M. (2017). Evaluating the Scalability of Public Participation in Urban Land Use Planning: a Comparison of Geoweb Methods with Face-To-Face Meetings. Environ. Plann. B: Urban Analytics City Sci. 46 (3), 511-533. doi:10.1177/ 2399808317719709

Jankowski, P. (2009). Towards Participatory Geographic Information Systems for Community-Based Environmental Decision Making. J. Environ. Manage. 90 (6), 1966-1971. doi:10.1016/j.jenvman.2007.08.028

Jenkins, H., Purushotma, R., Weigel, M., Clinton, K., and Robison, A. J. (2009). Confronting the Challenges of Participatory Culture. London: Media Education for the 21st Century, MacArthur. doi:10.7551/mitpress/8435. 001.0001

Jeon, Y., Herriges, J. A., Kling, C. L., and Downing, J. (2005). “The Role of Water Quality Perceptions in Modeling lake Recreation Demand,”. Department of Economics Working Papers Series. IDEAS/RePEc.

Jones, K. W., Powlen, K., Roberts, R., and Shinbrot, X. (2020). Participation in Payments for Ecosystem Services Programs in the Global South: a Systematic Review. Ecosystem Serv. 45, 101159. doi:10.1016/j.ecoser.2020.101159

Jurgoński, M., and Łowicki, D. (2020). "Rolnictwo Zrównoważone W Polsce Oraz Jego Wdrażanie I Postrzeganie W Gminie Kcynia," in Gospodarowanie Gruntami Na Obszarach Wiejskich. Editors A. Kołodziejczak and L. Kaczmarek (Poznań: Bogucki Wydawnictwo Naukowe), 129-147.

Kagan, O. (2020). Factors Associated with College Students' Willingness and Readiness to Act in a Food Allergic Emergency (WilRAFAE). J. Am. Coll. Health 68 (5), 484-493. doi:10.1080/07448481.2019.1577868

Kaila, H. L. (2005). Democratizing Schools across the World to Stop Killing Creativity in Children: An Indian Perspective. Counselling Psychol. Q. 18, 1-6. doi:10.1080/09515070500099728

Kaiser, F. G., Hübner, G., and Bogner, F. X. (2005). Contrasting the Theory of Planned Behavior with the Value-Belief-Norm Model in Explaining 
Conservation Behavior1. J. Appl. Soc. Pyschol 35 (10), 2150-2170. doi:10.1111/j. 1559-1816.2005.tb02213.x

Kollmuss, A., and Agyeman, J. (2002). Mind the Gap: Why Do People Act Environmentally and what Are the Barriers to Pro-environmental Behavior? Environ. Edu. Res. 8 (3), 239-260. doi:10.1080/13504620220145401

Kowalik, S. (2006). "Społeczność Lokalna a Kultura Regionalna," in Edukacja Regionalna. Editors A. Brzezińska, A. Hulewska, and J. Słomska (Warszawa: PWN), 21-45.

Kołodziejczak, A. (2018). The 2007-2013 Agri-Environmental Program as an Instrument for the Retardation of Natural Resources in Poland. J. Agribusiness Rural Dev. 2 (48), 143-151. doi:10.17306/J.JARD.2018.00413

Krishnaswamy, A. (2012). Strategies and Tools for Effective Public Participation in Natural Resource Management. J. Ecosyst. Manag. 13 (2), 1-13.

Langton, S. (1978). "What Is Citizen Participation?," in Citizen Participation in America: Esseys on the State of the Art. Editor S. Langton (Lexington: Lexington Books).

Lerner, J. S., Small, D. A., and Loewenstein, G. (2004). Heart Strings and Purse Strings. Carryover Effects of Emotions on Economic Decisions. Psychol. Sci. 15 (5), 337-341. doi:10.1111/j.0956-7976.2004.00679.x

Leszczyńska, A. (2016). Rola Emocji W Kształtowaniu Gotowości Do Zapłaty Za Dobra Środowiskowe. Optimum. Studia Ekonomiczne. 2 (80), 115-128. doi:10. 15290/ose.2016.02.80.09

Leventhal, H., and Scherer, K. (1987). The Relationship of Emotion to Cognition: a Functional Approach to a Semantic Controversy. Cogn. Emot. 1, 3-28. doi:10. 1080/02699938708408361

Linney, G. N., Henrys, P. A., Blackburn, G. A., Maskell, L. C., and Harrison, P. A. (2020). A Visualization Platform to Analyze Contextual Links between Natural Capital and Ecosystem Services. Ecosystem Serv. 45, 101189. doi:10.1016/j. ecoser.2020.101189

Lubell, M. (2002). Environmental Activism as Collective Action. Environ. Behav. 34 (4), 431-454. doi:10.1177/00116502034004002

Matczak, P. (2011). "Formy Partycypacji W Procesie Politycznym W Zakresie Ochrony Środowiska," in Partycypacja Publiczna. O Uczestnictwie Obywateli W Życiu Wspólnoty Lokalnej. Editor A. Olech (Warszawa: Instytut Spraw Publicznych), 131-155.

Matczak, P., Mączka, K., and Milewicz, M. (2015). E-partycypacja: Zastosowania Sondażu Internetowego Jako Narzędzia Partycypacyjnego. 10.14746/rpeis 77 (1), 239-256. doi:10.14746/rpeis.2015.77.1.13

Mizgajski, A. (2010). Świadczenia Ekosystemów Jako Rozwijające Się Pole Badawcze I Aplikacyjne. Ekonomia i Środowisko 1 (37), 10-19.

Murdock, B. S., Wiessner, C., and Sexton, K. (2005). Stakeholder Participation in Voluntary Environmental Agreements: Analysis of 10 Project XL Case Studies. Sci. Technol. Hum. Values 30 (2), 223-250. doi:10.1177/0162243904266104

Młodkowski, M., Walczak, D., and Jankowski, P. (2016). Projektowanie Zorientowane Na Użytkownika Oraz Metody Zwinnego Programowania W Procesie Tworzenia Geoportalu Wspierającego Partycypację Społeczną W Planowaniu Przestrzennym. Roczniki Geomatyki (Annals of Geomatics) 14 (5), 597-608.

Neef, A., and Neubert, D. (2011). Stakeholder Participation in Agricultural Research Projects: A Conceptual Framework for Reflection and DecisionMaking. Agric. Hum. Values 28 (2), 179-194. doi:10.1007/s10460-010-9272-z

Niedziałkowski, K., Paavola, J., and Jędrzejewska, B. (2012). Participation and Protected Areas Governance: the Impact of Changing Influence of Local Authorities on the Conservation of the Białowieża Primeval Forest, Poland. Ecol. Soc. 17 (1), 2. doi:10.5751/ES-04461-170102

Nielsen Global Corporate Sustainability Report (2015). The Sustainability Imperative. New Insights on Consumer Expectations. https://www.nielsen. com/us/en/press-releases/2015/consumer-goods-brands-that-demonstratecommitment-to-sustainability-outperform/.

Olech, A. (2012). "Modele Partycypacji Publicznej W Polsce," in Dyktat Czy Uczestnictwo? Diagnoza Partycypacji Publicznej W Polsce. Editor A. Olech A (Warszawa: Instytut Spraw Publicznych), 5-10.

Olech, A., and Kaźmierczak, T. (2011). "Modele Partycypacji Publicznej," in Partycypacja Publiczna. O Uczestnictwie Obywateli W Życiu Wspólnoty Lokalnej. Editor A. Olech (Warszawa: Instytut Spraw Publicznych), 100-111.

Ostrom, E. (1990). Governing the Commons: The Evolution of Institutions for Collective Action. Cambridge. UK: Cambridge University Press. doi:10.1017/ cbo9780511807763
Paavola, J., and Hubacek, K. (2013). Ecosystem Services, Governance, and Stakeholder Participation: Anintroduction. Ecol. Soc. 18 (4), 42. doi:10.5751/ es-06019-180442

Peisert, A., and Stachura, K. (2011). "Partycypacja Jako Wynik Rozwoju Technik Komunikowania I Zmian Charakteru Sfery Publicznej," in Partycypacja Publiczna. O Uczestnictwie Obywateli W Życiu Wspólnoty Lokalnej. Editor A. Olech (Warszawa: Instytut Spraw Publicznych), 45-60.

Pietras, M., and Myga-Piątek, U. (2005). "Własność Prywatna, Własność Publiczna: O Znaczeniu Posiadania Dla Kształtowania Krajobrazu Oraz Relacji Człowieka Z Miejscem I Przestrzenią," in Krajobraz Kulturowy. Aspekty Teoretyczne I Metodologiczne, Komisja Krajobrazu Kulturowego PTG. Editor U. Myga-Piątek (Sosnowiec, 78-89.

Reed, M. S., Hubacek, K., Bonn, A., Burt, T. P., Holden, J., Stringer, L. C., et al. (2013). Anticipating and Managing Future Trade-Offs and Complementarities between Ecosystem Services. Ecol. Soc. 18 (1), 5. doi:10.5751/es-04924-180105

Reed, M. S. (2008). Stakeholder Participation for Environmental Management: A Literature Review. Biol. Conservation 141, 2417-2431. doi:10.1016/j.biocon. 2008.07.014

Regulation of the Minister of the Environment (2008). Regulation on the Classification of Ecological Status, Ecological Potential, Chemical Status and the Method of Classifying the Status of Surface Water Bodies as Well as Environmental Quality Standards for Priority Substances. J. Law Available at: https://isap.sejm.gov.pl/isap.nsf/DocDetails.xsp?id=WDU20190002149 (Accessed May 15, 2021).

Renn, O. (2006). Participatory Processes for Designing Environmental Policies. Land Use Policy 23 (1), 34-43. doi:10.1016/j.landusepol.2004.08.005

Rowe, G., and Frewer, L. J. (2005). A Typology of Public Engagement Mechanisms. Sci. Technol. Hum. Values 30, 251-290. doi:10.1177/0162243904271724

Sargisson, R., de Groot, J., and Steg, L. (2020). The Relationship between Sociodemographics and Environmental Values across Seven European Countries. Front. Psychol. 11, 2253. doi:10.3389/fpsyg.2020.02253

Sawe, N., and Knutson, B. (2015). Neural Valuation of Environmental Resources. Neuroimage 122 (122), 87-95. doi:10.1016/j.neuroimage.2015.08.010

Shaheen, R. (2010). Creativity and Education. Ce 01 (3), 166-169. doi:10.4236/ce. 2010.13026

Shoyama, K., and Yamagata, Y. (2016). Local Perception of Ecosystem Service Bundles in the Kushiro Watershed, Northern Japan - Application of a Public Participation GIS Tool. Ecosystem Serv. 22 (A), 139-149. doi:10.1016/j.ecoser. 2016.10.009

Sobiesiak-Penszko, P., and Kotnarowski, M. (2012). "Partycypacja Publiczna W Polsce. Uwarunkowania Indywidualne I Kontekstowe,". Dyktat Czy Uczestnictwo? Diagnoza Partycypacji Publicznej W Polsce. Editor A. Olech (Warszawa: Instytut Spraw Publicznych), Vol. 1, 54-78.

Sodulski, W. (1999). 10 Lat Transformacji W Polsce - Ochrona Środowiska. Warszawa: Instytut na Rzecz Ekorozwoju.

Webler, T. (1995). "Right' Discourse in Citizen Participation: an Evaluative Yardstick," in Fairness and Competence in Citizen Participation: Evaluating Models for Environmental Discourse. Editors O. Renn, T. Webler, and P. Wiedemann (Dordrecht: Kluwer Academic).

Webler, T., Kastenholz, H., and Renn, O. (1995). Public Participation in Impact Assessment: a Social Learning Perspective. Environ. Impact Assess. Rev. 15 (5), 443-463. doi:10.1016/0195-9255(95)00043-e

Wesselink, A., Paavola, J., Fritsch, O., and Renn, O. (2011). Rationales for Public Participation in Environmental Policy and Governance: Practitioners' Perspectives. Environ. Plan. A. 43 (11), 2688-2704. doi:10.1068/a44161

Conflict of Interest: The authors declare that the research was conducted in the absence of any commercial or financial relationships that could be construed as a potential conflict of interest.

Copyright ( 2021 Cichon, Warachowska and Lowicki. This is an open-access article distributed under the terms of the Creative Commons Attribution License (CC BY). The use, distribution or reproduction in other forums is permitted, provided the original author(s) and the copyright owner(s) are credited and that the original publication in this journal is cited, in accordance with accepted academic practice. No use, distribution or reproduction is permitted which does not comply with these terms. 